\title{
Management-developing of an algorithm for the design decisions in the innovative activity of an organization
}

\author{
Yuri Polyakov ${ }^{1, *}$, Andrey Savchenko ${ }^{1}$, Mikhail Savelyev ${ }^{1}$, Denis Perevedentsev ${ }^{1}$ and Anna Koscheeva ${ }^{2}$ \\ ${ }^{1}$ Mitra Association, 241, Pushkinskaya Str., Izhevsk, 426008, Russia \\ ${ }^{2}$ Udmurt State University, 1, Universitetskaya Str., Izhevsk, 426034, Russia
}

\begin{abstract}
This article proposes a new algorithm for developing conceptual project decisions in terms of an organization or innovator's response to changing consumer demands through the development and investment in innovations. The theoretical basis for choosing the type of an algorithm was elaborated by studying the available referencies relevant to present issues of the applicability of types of algorithms for developing management decisions. A multistage multicriteria algorithm (hereinafter referred to as MMA) was developed on the basis of studied algorithms. On developing the stages of the MMA, a set of thinking methods (analysis - synthesis, deduction - induction), a decomposition method, and logical methods were used. MMA is considered as a set of step-by-step sequential descriptions of local processes, formulations and solutions of management tasks, used decision methods and decision-making criteria. The SMART(ER) method was used for managerial tasks at each stage to be set. When solving a management problem, a set of methods was used including an expert method, a factor analysis, brainstorm and methods for calculating economic efficiency. For choosing solutions at each stage to be made, a set of criteria was used. They are the weight of the negative impact on the result of the activity, the yes/no method, the maximum effect, costs minimizing, risks. The schematic design was defined for MMA to be developed. The schematic design was considered as a method of modeling and a method of graphical-analytical displaying of the stages of the process.
\end{abstract}

\section{Introduction}

The object of the research is the management and driving innovation. The algorithmic methods for making management decisions are under study.

The purpose of the research is to develop an algorithm for developing conceptual design decisions.

To solve the problems of conceptual design and development of complex self-organizing systems, large amounts of data are used today from heterogeneous and distributed sources, when working with which special highly loaded information systems for extracting data and knowledge about the characteristics of the project are created.

A high share of the uncertainty of this problem requires special methodological approaches to the analysis of the organization's response to a change in the structure of consumer needs, in the list of such approaches: expert assessment of knowledge about the behavior of stakeholders [1], system analysis of the links between the organizational structure and the workforce and information systems that support it [ 2,9], planning the development of a project based on the theory of constraints and the critical chain method [3, 12], structural analysis of the social graph and the interconnections of project subsystems [13].

Highly specialized models of projects of organizational systems are being developed, so
Takenberg S., Dukwitz S. and Shlik K. proposed a design and engineering approach including the analysis of process and actor-oriented behavior of system elements [5]. Bukhin E. and Rozens H. [6] presented a multipurpose optimization model of decision making in the implementation of a project based on the analysis of many alternative options. The authors of the article [7] describe examples of solving optimization problems of project development in various subject areas on the basis of their proposed approach "project tree", which is a tree-like structure of decision-making in time. The authors of $[8,10,11]$ proposed graphical structures for generating knowledge about a project by situational and thematic analysis of its life cycle. The work [14] presents an optimization model for solving the problem of process planning and project support, taking into account the limitations of several executive modes and a managerial approach to the versatility of employees and prioritization of tasks.

The growing demand for special intelligent data processing systems is due to the need for digitalization of production processes, which is confirmed by new research in this area. For example, in [4], knowledgebased decision-making expert systems (KBDSS) are classified into three categories: technologies for modeling and knowledge representation, technologies for reasoning and inference, and web technologies, and recommendations for their integration into service

* Corresponding author: $\underline{\text { savaisai@gmail.com }}$ 
production systems are developed. The authors of [15] proposed analytical approaches to the development and training of an autonomous algorithm for predicting the characteristics of projects, [16] presents a model method based on the registration and subsequent classification of facts about the operation of various organizational and engineering systems for data mining and estimation of project parameters. A study by the authors [17] describes a new approach to obtaining specific knowledge and making decisions to accelerate the development of expert systems, based on the generation of linguistic rules and replenishment of the base of heuristic expert knowledge.

Thus, recommender systems become an integral element of the processes of formation of expert knowledge and decision-making with collaborative filtering of alternatives, representing the modeling of the degree of confidence in the context of available incomplete data $[19,20]$. Sakama S. and Inue K. In the article [18], they showed the importance of the abductive approach, including the analysis of the actual course of processes in organizational systems, and the search for explanatory hypotheses in the formation of new knowledge, since it is based on new relevant facts about the development of the project.

In our opinion, it is possible to develop an algorithm by introducing the concept of an innovative complex.

The innovative complex of the organization consists of the following structural elements:

- innovation and product complex which is a set of types and costs of work on the development of a product;

- innovation and technological complex which is a set of types and costs of work on the development of technologies;

- complex of innovative materials which is set of types and costs of work on the development of innovative materials.

\section{Materials and Methods}

The relevance of the study is due to the need to solve one of the priority management tasks aka the adaptation of the activities of managers during the transition to the digital economy, used for the processes of choosing the type and quality of a homogeneous product, usefulness for the consumer and manufacturer, and other consumer properties to an algorithm [21-24]. The main proposed approach to the management of the design of an innovative algorithm is the schematic design. Algorithm design Management-Developing of the algorithm is proposed to be carried out in the following sequence:

- analysis of the management situation in the organization;

- statistical observation;

- analysis of the management situation in innovation;

- putting forward/refuting hypotheses, structural elements of hypotheses that contribute to the appearance of adverse symptoms in the activities of the organization; - identifying the reasons, methods for choosing and organizing an innovative system;
- formulation of problems, the discrepancy between the methods of selection and organization of the innovative system, certain criteria;

- putting forward/refuting alternatives, to solve the task of the innovative system.

\section{Results and Discussion}

Stage 1. Analysis of the management situation in the organization.

Using the method of factor analysis it is proposed to identify trends and factors that determine the tendencies in the results of the organization's activities, to assess the weight of the influence of a particular factor on the resulting indicator of the organization's performance, to identify the most weighty indications by the criterion of weight and to graphically simulate the results of the analysis in the form of a sketch. A sketch of the analysis results is shown in Figure 1.

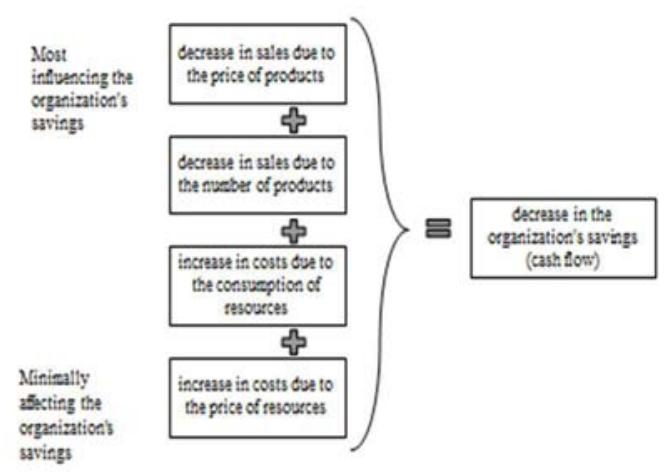

Fig. 1. The results of the analysis of the organization's activities

Stage 2. Statistical observation

It is proposed using the decomposition method to establish the relationship between the main results and factors that determine the trends of innovation with the results of the organization as a whole, etc. graphically with modeling as a sketch. A sketch of the decomposition results is shown in Figure 2. 


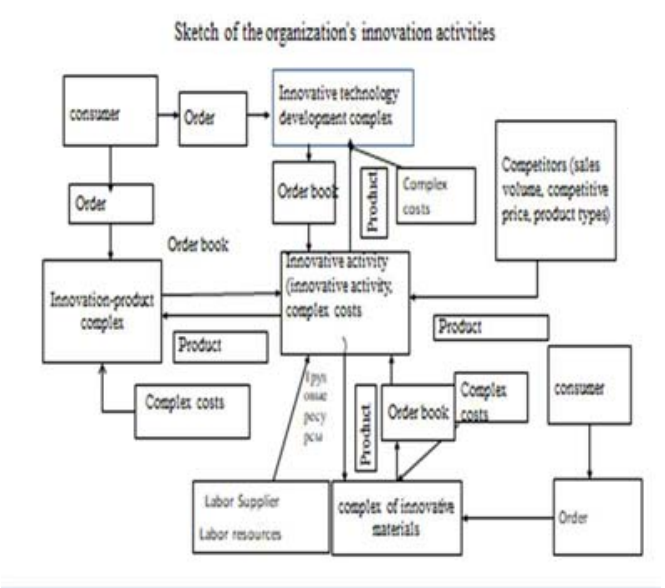

Fig. 2. Sketch of the organization's innovation activities

Stage 3. Analysis of the management situation in innovation

It is proposed, using the method of factor analysis, to identify trends and factors that determine the tendencies in the results of innovative activities of the organization, to assess the weight of the influence of a particular factor on the resulting indicator of the organization's innovative activity, to identify the most weighty indications by the criterion of weight and to graphically simulate the results of the analysis as a sketch. A sketch of the analysis results is shown in Figure 3.

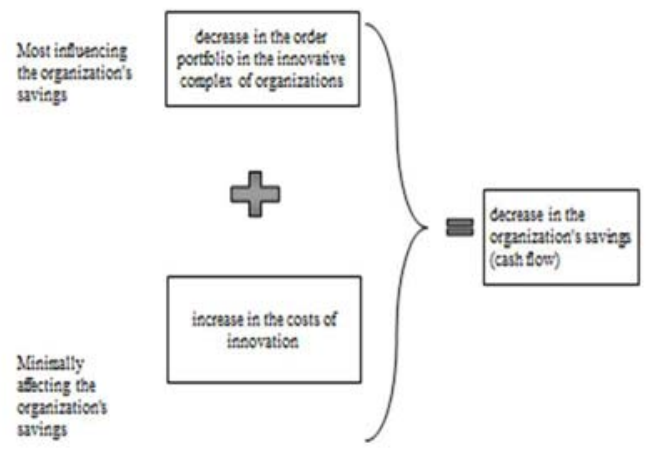

Fig. 3. An example of the result of the processes of identifying the set and selection of the most significant negative symptom of negative symptoms

Stage 4. Description of hypotheses

It is proposed, using logical methods and the decomposition method, to construct the structural elements and parameters of the hypothesis, using the factor analysis method to establish the correlation between possible changes in innovation and the appearance of the most significant negative trends in the organization's activities. One of the possible theoretical hypotheses is presented in Table 1.

Table 1. The relationship "changes in the innovative complex is the most significant negative symptom"

\begin{tabular}{|c|c|c|c|}
\hline $\begin{array}{c}\text { Types of } \\
\text { innovative } \\
\text { activities of } \\
\text { the } \\
\text { organization } \\
\text { (hypothesis) }\end{array}$ & $\begin{array}{l}\text { Organizational } \\
\text { performance } \\
\text { indicator } \\
\text { (most } \\
\text { significant } \\
\text { negative } \\
\text { indication) } \\
\end{array}$ & $\begin{array}{l}\text { Changing } \\
\text { the } \\
\text { structural } \\
\text { elements of } \\
\text { the } \\
\text { hypothesis }\end{array}$ & $\begin{array}{l}\text { Changing the } \\
\text { parameters of } \\
\text { structural } \\
\text { elements }\end{array}$ \\
\hline $\begin{array}{l}\text { Innovation } \\
\text { and product } \\
\text { system }\end{array}$ & \multirow{4}{*}{$\begin{array}{c}\text { Decrease in } \\
\text { sales volume } \\
\text { due to product } \\
\text { price }\end{array}$} & $\begin{array}{l}\text { Decrease in } \\
\text { the business } \\
\text { acquisition }\end{array}$ & $\begin{array}{l}\text { R\&D, TESTS, } \\
\text { PILOT } \\
\text { PRODUCTION }\end{array}$ \\
\hline $\begin{array}{c}\text { Innovative } \\
\text { and } \\
\text { technological } \\
\text { system }\end{array}$ & & $\begin{array}{c}\text { Decrease } \\
\text { in the } \\
\text { business } \\
\text { acquisition }\end{array}$ & $\begin{array}{l}\text { R\&D, TESTS, } \\
\text { PILOT } \\
\text { PRODUCTION }\end{array}$ \\
\hline $\begin{array}{c}\text { Innovative } \\
\text { materials }\end{array}$ & & $\begin{array}{l}\text { Decrease in } \\
\text { the business } \\
\text { acquisition }\end{array}$ & $\begin{array}{l}\text { R\&D, TESTS, } \\
\text { PILOT } \\
\text { PRODUCTION }\end{array}$ \\
\hline Competitors & & $\begin{array}{l}\text { Increase of } \\
\text { competitors' } \\
\text { business } \\
\text { acquisition }\end{array}$ & $\begin{array}{c}\text { Production } \\
\text { capacity }\end{array}$ \\
\hline
\end{tabular}

According to the criterion of weight, it is proposed to select the problematic structural element-parameter and graphically simulate the results of the analysis as a sketch. A sketch of the results of describing hypotheses is shown in Figure 4.

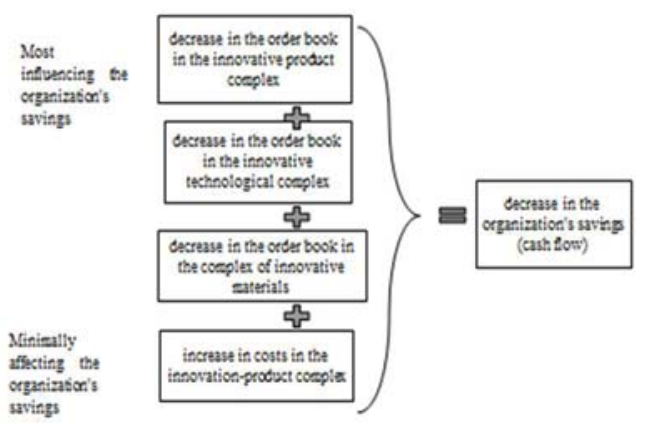

Fig. 4. Causal relationship "parameter - element - innovative activity - symptom"

Stage 5. Identifying the causes

It is proposed, using the grouping method, to group the causes into two groups: a set of causes influencing the appearance of a negative indication, due to the process of justifying the plan (investment plan and distribution of investments by types of innovative complexes localized in geographic markets) and a set of causes influencing the appearance of a negative 
symptom, due to the process of organizing work on the innovative complexes of the organization. By the interviewing specialists, by the method of compliance (yes/no), it is proposed to identify the essential factors. According to the criterion of significance, it is proposed to choose a significant factor and graphically simulate the results of identifying the cause factors in the form of a table. The results of identifying the causes are shown in Table 2.

Table 2. Results of identifying causes

\begin{tabular}{|c|c|c|c|c|}
\hline \multirow[b]{2}{*}{$\begin{array}{l}\text { Types of } \\
\text { innovative } \\
\text { activities } \\
\text { of the } \\
\text { organizati } \\
\text { on } \\
\text { (hypothesi } \\
\text { s) }\end{array}$} & \multirow{2}{*}{$\begin{array}{l}\text { Problemat } \\
\text { ic } \\
\text { structural } \\
\text { element }\end{array}$} & \multirow{2}{*}{$\begin{array}{l}\text { Changing the } \\
\text { parameters of } \\
\text { structural } \\
\text { elements }\end{array}$} & \multicolumn{2}{|c|}{ Causes } \\
\hline & & & $\begin{array}{c}\text { Justificati } \\
\text { on }\end{array}$ & $\begin{array}{l}\text { Organizati } \\
\text { on }\end{array}$ \\
\hline $\begin{array}{l}\text { Innovation } \\
\text { and } \\
\text { product } \\
\text { system }\end{array}$ & $\begin{array}{l}\text { Decrease } \\
\text { in the } \\
\text { business } \\
\text { acquisitio } \\
\text { n of the } \\
\text { innovative } \\
\text { product } \\
\text { complex }\end{array}$ & $\begin{array}{c}\text { R\&D, } \\
\text { TESTS, } \\
\text { PILOT } \\
\text { PRODUCTI } \\
\text { ON }\end{array}$ & $\begin{array}{l}\text { No plan to } \\
\text { develop } \\
\text { new } \\
\text { products }\end{array}$ & $\begin{array}{l}\text { No work } \\
\text { on the pilot } \\
\text { production }\end{array}$ \\
\hline
\end{tabular}

\section{6 stage. Formulating problems}

It is proposed using the conformity method (yes / no) to establish a set of problems in the processes of justifying the plan and a set of problems in the processes of organizing work on the innovative complexes of the organization. According to the weight criterion proposed to select a significant issue and by graphical modeling we develop a table of the results of problem formulation. See Table 3.

Table 3. Problem Formulation Results

\begin{tabular}{|c|c|c|c|c|}
\hline \multirow[b]{2}{*}{$\begin{array}{c}\text { Types of } \\
\text { innovative } \\
\text { activities } \\
\text { of the } \\
\text { organizati } \\
\text { on } \\
\text { (hypothesi } \\
\text { s) }\end{array}$} & \multirow{2}{*}{$\begin{array}{l}\text { Problemat } \\
\text { ic } \\
\text { structural } \\
\text { element }\end{array}$} & \multirow{2}{*}{$\begin{array}{l}\text { Changing the } \\
\text { parameters of } \\
\text { structural } \\
\text { elements }\end{array}$} & \multicolumn{2}{|c|}{ Problems } \\
\hline & & & $\begin{array}{c}\text { Justificati } \\
\text { on }\end{array}$ & $\begin{array}{c}\text { Organizatio } \\
n\end{array}$ \\
\hline $\begin{array}{l}\text { Innovation } \\
\text { and } \\
\text { product } \\
\text { system }\end{array}$ & $\begin{array}{l}\text { Decrease } \\
\text { in the } \\
\text { business } \\
\text { acquisitio } \\
n \text { of the } \\
\text { innovative } \\
\text { product } \\
\text { complex }\end{array}$ & $\begin{array}{c}\text { R\&D, } \\
\text { TESTING, } \\
\text { PILOT } \\
\text { PRODUCTI } \\
\text { ON }\end{array}$ & $\begin{array}{c}\text { No } \\
\text { prediction } \\
\text { on the } \\
\text { emergenc } \\
\text { e of a new } \\
\text { product of } \\
\text { competito } \\
\text { rs }\end{array}$ & $\begin{array}{l}\text { Lack of } \\
\text { competenci } \\
\text { es in the } \\
\text { modern } \\
\text { organizatio } \\
\mathrm{n} \text { of work } \\
\text { in pilot } \\
\text { production }\end{array}$ \\
\hline
\end{tabular}

Stage 7. Putting forward / refutation of alternatives for solving complex problems

It is proposed, using the brainstorming method and the scenario method, to form a set of alternatives for solving problems in the processes of substantiating the plan and in the processes of organizing work, to graphically model the formulation of a set of alternatives in the form of a table of results. The results of definition of alternatives are shown in Table 4.
Table 4. Set of alternatives

\begin{tabular}{|c|c|c|c|}
\hline \multirow{2}{*}{$\begin{array}{l}\text { Problematic } \\
\text { structural } \\
\text { element }\end{array}$} & \multirow{2}{*}{$\begin{array}{l}\text { Changing the } \\
\text { parameters of } \\
\text { structural } \\
\text { elements }\end{array}$} & \multicolumn{2}{|c|}{ A set of alternatives } \\
\hline & & Justification & Organization \\
\hline $\begin{array}{l}\text { Decrease in } \\
\text { the business } \\
\text { acquisition of } \\
\text { the } \\
\text { innovative } \\
\text { product } \\
\text { complex }\end{array}$ & $\begin{array}{c}\text { R\&D, TESTING, } \\
\text { PILOT } \\
\text { PRODUCTION } \\
\ldots\end{array}$ & $\begin{array}{c}\text { Develop or } \\
\text { upgrade a } \\
\text { product }\end{array}$ & $\begin{array}{c}\text { To develop } \\
\text { or order a } \\
\text { project to } \\
\text { organize a } \\
\text { pilot } \\
\text { production } \\
\text { of an } \\
\text { innovative } \\
\text { product } \\
\text { system }\end{array}$ \\
\hline
\end{tabular}

It is proposed to form a sketch and graphically simulate in the form of a sketch the effectiveness of the innovation-product complex.

A sketch of the effectiveness of the innovation and product complex is shown in Figure 5.

\section{Sketch of the efficiency of the innovation and product complex}

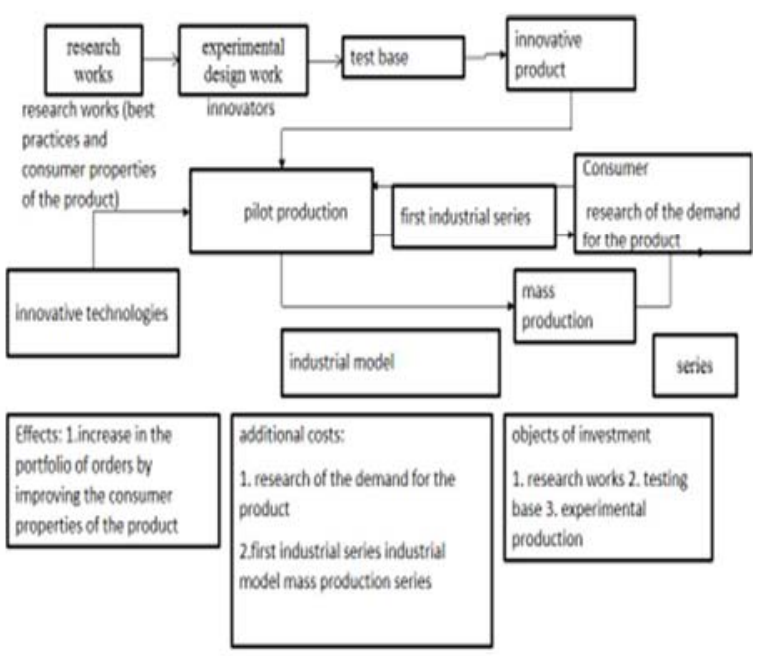

Fig. 5. Sketch of the efficiency of the innovation and product complex

According to the criterion of the maximum annual reduced effect, it is proposed to choose an alternative and graphically simulate the results of the choice of alternatives in the form of a table. The results of the choice of alternatives are shown in Table 5.

Table 5. Results of choosing alternatives 


\begin{tabular}{|l|l|l|}
\hline $\begin{array}{l}\text { Main } \\
\text { challenges }\end{array}$ & $\begin{array}{l}\text { Alternatives to } \\
\text { increasing the } \\
\text { capabilities of } \\
\text { the innovation } \\
\text { and product } \\
\text { complex }\end{array}$ & $\begin{array}{l}\text { Calculation of the } \\
\text { annual reduced } \\
\text { economic effect }(\Delta \mathrm{PV}) \\
\text { from the } \\
\text { implementation of } \\
\text { alternatives, million } \\
\text { rubles. }\end{array}$ \\
\hline $\begin{array}{l}\text { No prediction } \\
\text { of a new } \\
\text { product } \\
\text { developed by } \\
\text { competitors }\end{array}$ & $\begin{array}{l}\text { Ueveloping a } \\
\text { product } \\
\text { product }\end{array}$ & $\begin{array}{l}\Delta \mathrm{PV} \mathrm{p} \text { - due to product } \\
\text { development }\end{array}$ \\
\cline { 2 - 3 } & $\begin{array}{l}\Delta \mathrm{PV} \mathrm{m} \text { - due to product } \\
\text { upgrades }\end{array}$ \\
\hline $\begin{array}{l}\text { The most significant negative } \\
\text { symptom (decreased sales of the } \\
\text { organization) }\end{array}$ & $\begin{array}{l}\Delta \mathrm{PV} \mathrm{p}>\Delta \mathrm{PV} \mathrm{m}- \\
\text { choose } \\
\text { development }\end{array}$ \\
\hline \multicolumn{2}{|l|}{ product } \\
\hline
\end{tabular}

7-stage MMA for the development process of conceptual design solutions in the innovation of the organization of the system consistently describes the operations (actions) of the manager in specific management situations. MMA enables a book of order and the organization development program to be formed.

\section{Conclusions}

Following from available referencies relevant to the study [25-37] it can be concluded that the proposed algorithm (MMA) is unique as compared to well known.

Novelty of MMA comprises the way of its embedding in logic of innovative system and two stages that are nomination or refutation of hypotheses and identification the causes of adverse effects. The MMA can be used by specialists in the development of management activities in a monocultural innovation organization.

\section{Acknowledgements}

The reported study was funded by RFBR, project number 20-010-00869.

\section{References}

1. F. Caron,. Int. J. of Data Science, 1- 1, 42-57, (2015)

2. H. Kerzner, Project Governance. Project Management 2.0, (2015)

3. Q. Yuan, Y. Polychronakis, Int. J. of Project Organisation and Management, 4, 339 - 367. 4 (2012)

4. P. Zarate, Sh. Liu, International Journal of Information and Decision Sciences (IJIDS), 8, $305-324,3(2016)$

5. S. Tackenberg, S. Duckwitz, Ch. Schlick, Int. J. of Computer Aided Engineering and Technology, 2, $414-435,4(2010)$
6. Y. Bukchin, Sh. Rozenes,. Int. J. of Project Organisation and Management, 3, 184 - 203, 2(2011)

7. A. Muhlemann, A. Lockett, A. Gear, Decision Sciences, 9, 612-626, (1978)

8. M. Daradkeh, Int. J. of Information and Decision Sciences, 9, 276 - 296, 3(2017)

9. R. Burke, S. Barron, Project Organization Structures. Project Management Leadership, (2015)

10. S. Lippe, J. Brocke, Project Management Journal. 47, 76-96, (2016)

11. M. Gorog, Project Management Journal, 42, 1731 (2011)

12. D. McLain, Project Management Journal, 40, 6073, (2009)

13. P. Chinowsky, J. Taylor, Engineering Project Organization Journal, 2, 15-26, 1-2(2012)

14. Q. Liu, X. Geng, M. Dong, Ch. Ye, Engineering Optimization, 49, 896-914, 5 (2017)

15. L. Shi, L. Newnes, S. Culley, B. Artificial Intelligence for Engineering Design, Analysis and Manufacturing, 31, 313-326, 3 (2017).

16. M. Quaglio, E. Fraga, E. Cao, A. Gavriilidis, F. Galvanin, Chemometrics and Intelligent Laboratory Systems, 172, (2018).

17. H. Xing, S. Huang, J. Shi, Artificial Intelligence for Engineering Design, Analysis and Manufacturing, 17, 221-234, 3 (2003)

18. C. Sakama, K. Inoue, Theory and Practice of Logic Programming, 31, 671-715, 3 (2003)

19. F. Gohari, F. Aliee, H. Haghighi, Information Sciences. 422, 21-50, (2018)

20. J. Herlocker, J. Konstan, L. Terveen, J. Riedl, Journal ACM Transactions on Information System, 22, 5-53, 1(2004)

21. Yu. Polyakov, M. Savelyev, D. Perevedentsev, O. Titova, M. Galiakhmetova, SHS Web of Conf, 89 01007 (2020)

22. Yu. Polyakov, A. Savchenko, N. Alekseeva, E. Panteleeva, M. Savelyev, SHS Web of Conf, 89 01006 (2020)

23. Yu. Polyakov, M. Savelyev, A. Savchenko, Problems of regional economy, 1-2, 186 (2020)

24. M. Savelyev, Problems of regional economy, 3-4, 133-140, (2020)

25. D. Meissner, M. Kotsemir,. J Innov Entrep 5, 14 (2016)

26. F. Pleschak, H. Sabisch, Innovationsmanagement. (Stuttgart: Schäffer-Poeschl. 1996)

27. J. Witt, Produktinnovation: Entwicklung und Vermarktung neuer Produkte. (München: Vahlen, 1996)

28. G. Ebert, F. Pleschak, H. Sabisch, Bericht Fraunhofer-Institut für Systemtechnik und Innovationsforschung. (Wiesbaden: Gabler, 1992) 
29. W. Durfee, P. Iaizzo, Engineering in Medicine, Academic Press, 495-509, (2019)

30. G. Hughes, D. Chafin, J Prod Innov Manag, (1996)

31. R. Cooper, M. DeGroote, Overhauling the new product process. (Ind Mark Manage, 1996)

32. K. Ulrich, S. Eppinger, M. Yang, Product Design and Development, (Columbus: McGraw Hill, 2020)

33. C. Crawford, C. Di Benedetto, New Products Management. (Columbus: McGraw-Hill, 2021)

34. K. Brockhoff. Forschung und Entwicklung Planung und Kontrolle. (Berlin: De Gruyter, 1999)

35. R. Rothwell, International Marketing Review, 11, 7 - 31, 1(1994).

36. A. Berkhout, D. Hartmann, P. Duin, R. Ortt, Int. J. Technology Management, 34. 390-404. 3/4 (2006)

37. S. Kline, N. Rosenberg, An overview of innovation. The positive sum strategy: Harnessing technology for economic growth. (Washington: National Academy Press, 1986) 